TABLA I

ERITEMA INDURADO

\begin{tabular}{|c|c|c|c|c|c|c|}
\hline & $\begin{array}{l}\text { Edad/sexol } \\
\text { año dx }\end{array}$ & $\begin{array}{l}\text { Antecedentes } \\
\text { TBC }\end{array}$ & $\begin{array}{l}\text { Motivo de } \\
\text { consulta }\end{array}$ & Mantoux & $\begin{array}{l}\text { Biopsia } \\
\text { cultivo/PCR }\end{array}$ & $\begin{array}{l}\text { Tratamiento/ } \\
\text { evolución }\end{array}$ \\
\hline 1 & $62 / M(2001)$ & No recuerda & $\begin{array}{l}\text { Semanas de brotes } \\
\text { lesiones MMll y antebrazos, fiebre }\end{array}$ & No & $\begin{array}{l}\text { PLCV } \\
\text { Cultivo- }\end{array}$ & EXITUS por linfoma \\
\hline 2 & 70/M (2001) & TBC intestinal & 8 meses de brotes MMII, artralgias & $25 \mathrm{~mm}$ & $\begin{array}{l}\text { PLCV } \\
\text { Cultivo- } \\
\text { PCR- }\end{array}$ & "Rifampicina, isoniazida, pirazinamida \\
\hline 3 & 58/M (2002) & No recuerda. & 1 mes de brotes brazos, MMII & $18 \mathrm{~mm}$ & $\begin{array}{l}\text { PLCV } \\
\text { Cultivo- }\end{array}$ & $\begin{array}{l}\text { Sintomá tico } \\
\text { No acudió a revisión }\end{array}$ \\
\hline 4 & $30 / M(2004)$ & Contacto TBC pulmonar & Años brotes MMII & $16 \mathrm{~mm}$ & $\begin{array}{l}\text { PLCV } \\
\text { Cultivo- } \\
\text { PCR- }\end{array}$ & $\begin{array}{l}\text { Sintomá tico. } \\
\text { No ha vuelto a tener brotes }\end{array}$ \\
\hline 5 & $75 / \mathrm{M}(2005)$ & No recuerda & Añ os brotes MMII, artralgias, aftas orales & $15 \mathrm{~mm}$ & $\begin{array}{l}\text { PLCV } \\
\text { Cultivo- } \\
\text { PCR- }\end{array}$ & $\begin{array}{l}\text { Sintomá tico. } \\
\text { No acudió a revisión }\end{array}$ \\
\hline 6 & $54 / \mathrm{M}(2006)$ & Pleura juventud & 1 añ o brotes MMIII, artralgias & Positivo & $\begin{array}{l}\text { PLCV } \\
\text { Cultivo- } \\
\text { PCR- }\end{array}$ & "Rifampicina, isoniazida, pirazinamida \\
\hline 7 & 63/M (2007) & No recuerda & 6 meses brotes MMII & $10 \mathrm{~mm}$ & $\begin{array}{l}\text { PLCV } \\
\text { Cultivo- } \\
\text { PCR- }\end{array}$ & "Rifampicina, isoniazida, pirazinamida \\
\hline 8 & 78/M (2007) & Contacto TBC & 1 mes brotes MMII & Negativo & PLCV & $\begin{array}{l}\text { Sintomático } \\
\text { Pendiente de evolución }\end{array}$ \\
\hline 9 & 28/H (2003) & No recuerda & 1 mes brazo dcho, aftas orales & NO & PLCV & $\begin{array}{l}\text { Sintomá tico } \\
\text { No ha vuelto a tener brotes }\end{array}$ \\
\hline 10 & $57 / H(2005)$ & No recuerda & 2 meses brotes MMII & $10 \mathrm{~mm}$ & $\begin{array}{l}\text { PLCV } \\
\text { Cultivo- } \\
\text { PCR- }\end{array}$ & $\begin{array}{l}\text { Sintomá tico } \\
\text { Pendiente de evolución }\end{array}$ \\
\hline 11 & $60 / H(2007)$ & No recuerda & 1 mes brotes MMII, artralgias & $40 \mathrm{~mm}$ & $\begin{array}{l}\text { PLCV } \\
\text { Cultivo- }\end{array}$ & "Rifampicina, isoniazida, pirazinamida \\
\hline
\end{tabular}

MMII: miembros inferiores. PLCV: paniculitis lobulillar con vasculitis. * Rifampicina, isoniazida, pirazinamida 2 meses. Rifampicina, isoniazida 4 meses.

5. Leow LJ, Pintens S, Pigott PC, Whitfeld MJ. Erythema induratum- a hypersensitivity reaction to Mycobacterium tuberculosis. Aust Fam Physician 2006; 35: 521-2.

6. Lafuente Urrez RF, Dachary Pagola MT, Ruiz Laiglesia F. Nodular lesions of the lower limbs with long clinical course. Bazin's indurated erythema. An Med Interna (Madrid) 2003; 20: 498.

\section{Neumonía y espondilodiscitis lumbar como complicación de una bacteriemia por Staphylococcus aureus}

\section{Sr. Director:}

Staphylococcus aureus es responsable de menos del 10\% de los casos de neumonía adquirida en la comunidad, confirmados microbiológicamente (1), pero se estima que es responsable de cerca del $30 \%$ de los casos de neumonías adquiridas en el hospital (2).

Afecta principalmente a pacientes ancianos que viven en residencias (3) y también a personas que tienen factores predisponentes como son la diabetes mellitus, alcoholismo y muy típicamente durante las epidemias de gripe (4).

Las manifestaciones clínicas de la neumonía por Staphylococcus aureus son indistinguibles de las que presentan los pacientes con neumonías producidas por otros microorganismos, aunque en el caso de los estafilococos, es más frecuente que se produzca infección necrosante con cavitación(5).

Puede adquirirse tanto por vía aérea o aspiración, como secundaria a la siembra hematógena durante una bacteriemia (5).

Recientemente hemos tenido ocasión de diagnosticar a un paciente que tuvo una bacteriemia por Staphylococcus aureus, sin endocarditis; presentando un cuadro de neumonía y además una espondilodiscitis lumbar. Dado el interés del caso, nos parece conveniente presentarlo a continuación.

Varón de 75 años de edad, con antecedentes personales de intervención por cáncer de laringe hacía 10 años, sin datos actuales de recidiva, no fumador desde entonces; diagnosticado de enfermedad pulmonar obstructiva crónica, en tratamiento con teofilina retardada, no oxigenoterapia domiciliaria ni ingresos por éste motivo; hipertensión arterial en tratamiento con captopril; no alergias medicamentosas conocidas; posible cólico nefroureteral derecho quince días antes.

Acudió a urgencias refiriendo incremento de su disnea habitual de unos cinco días de evolución, acompañada de tos con escasa expectoración blanquecino-amarillenta, ruidos respiratorios, fiebre de hasta $38^{\circ} \mathrm{C}$ y cierta desorientación en las últimas 24 horas. Su médico había indicado tratamiento con moxifloxacino y un mucolítico, sin mejoría.

A la exploración física: T.A: $155 / 80 \mathrm{mmHg}, 38{ }^{\circ} \mathrm{C}$, obeso, facies congestiva, traqueostomía. Auscultación cardiaca: Tonos rítmicos ligeramente rápidos. Auscultación pulmonar: Estertores crepitantes en la base derecha, sibilancias difusas y disminución global del murmullo vesícular, más acusado en la base derecha. 
Abdomen: blando, globuloso, depresible, no doloroso, no organomegalias. No edemas maleolares ni datos sugerentes de trombosis venosa profunda.

Laboratorio Hemograma: 18.500 leucocitos con 16.500 neutrófilos, hemoglobina de 15,7 g/dl, 129.000 plaquetas; actividad de protrombina del $88 \%$ con INR de 1,1; Bioquímica, destacó glucemia de $213 \mathrm{mg} / \mathrm{dl}$. Orina elemental, normal. Gasometría arterial basal: pH: 7,45, $\mathrm{pO}_{2}: 44 \mathrm{mmHg}, \mathrm{pCO}_{2}: 45 \mathrm{mmHg}, \mathrm{C} 03 \mathrm{H}$ : $29,4 \mathrm{mmol} / \mathrm{l}$

Radiografía de tórax: Condensación en base y campo medio del pulmón derecho.

E.C.G: Taquicardia sinusal, bloqueo incompleto de la rama derecha de Haz de Hiss.

Con el diagnóstico de neumonía derecha en paciente con EPOC, insuficiencia respiratoria parcial y diabetes mellitus, ingresó inicialmente en la planta de Medicina Interna, pero la evolución fue rápidamente desfavorable, presentando incremento del trabajo respiratorio, fiebre elevada, deterioro del nivel de conciencia y empeoramiento gasométrico, por lo que fue trasladado a la UVI a las 24 horas; donde se procedió a intubación y conexión a ventilación mecánica, además necesitó tratamiento inotrópico con noradrenalina, fluidoterapia, corticoides y levofloxacino.

Se aisló Staphylococcus aureus, meticilin sensible en cuatro hemocultivos y en cultivos protegidos del tracto respiratorio inferior, por lo que se añadió tratamiento con cloxacilina.

Un ecocardiograma no mostró vegetaciones.

La evolución posterior fue favorable, pudiendo suspender la ventilación mecánica a los cinco días y procediendo al traslado a la planta de Medicina Interna nuevamente.

En dicho servicio, presentó diversos problemas respiratorios (tapón de moco, broncoespasmo, etc.), pero sin precisar nuevo ingreso en UVI.

Asimismo refería dolor sobre las apófisis espinosas L4-L5, de características mecánicas, por lo que se solicitó una gammagrafía ósea.

Fue dado de alta a los dieciocho días del ingreso inicial, indicando tratamiento con oxigenoterapia domiciliaria, bromuro de tiotropio, salmeterol y fluticasona en inhalador y prednisona oral.

El informe de la gammagrafía ósea fue de lesión en la charnela lumbosacra probablemente de naturaleza degenerativa, recomendando la realización de otra prueba de imagen. Se realizó una TAC y posteriormente una resonancia nuclear magnética de la columna lumbar, apreciándose protusiones discales L2- L3, L3L4 y L5-S1 y además en el espacio L4-L5 se evidenció una mala definición del contorno discal con hiposeñal T1 e hiperseñal en T2, con áreas de hiposeñal en los platillos adyacentes, altamente sugerente de espondilodiscitis (Fig. 1).

Completó 6 semanas de tratamiento antibiótico con cloxacilina.

La evolución posterior fue favorable, no volviendo a presentar fiebre ni dolor lumbar, continuando sus revisiones con el servicio de Neumología.

En resumen nuestro paciente presentó una bacteriemia por Staphylococcus aureus, complicada con una neumonía y una espondilodiscitis.

La osteomielitis está producida mayoritariamente por Staphylococcus aureus en el 50-70\% de los casos (6). Las bacterias pueden infectar el hueso a través de una siembra hematógena o por contiguidad.

La osteomielitis se clasifica en aguda y crónica; la aguda se define como el primer episodio que responde al tratamiento médico en las primeras 6 semanas(6).

Para prevenir la osteonecrosis y para evitar el paso de osteomielitis aguda a crónica es obligado la instauración rápida de antibióticos, durante 4-6 semanas( 7).

La incidencia de osteomielitis está reduciéndose, lo que refleja un mejor control de las infecciones banales cutáneas y de tejidos blandos por Staphylococcus aureus, que constituyen a menudo la fuente de las bacteriemias transitorias(5).

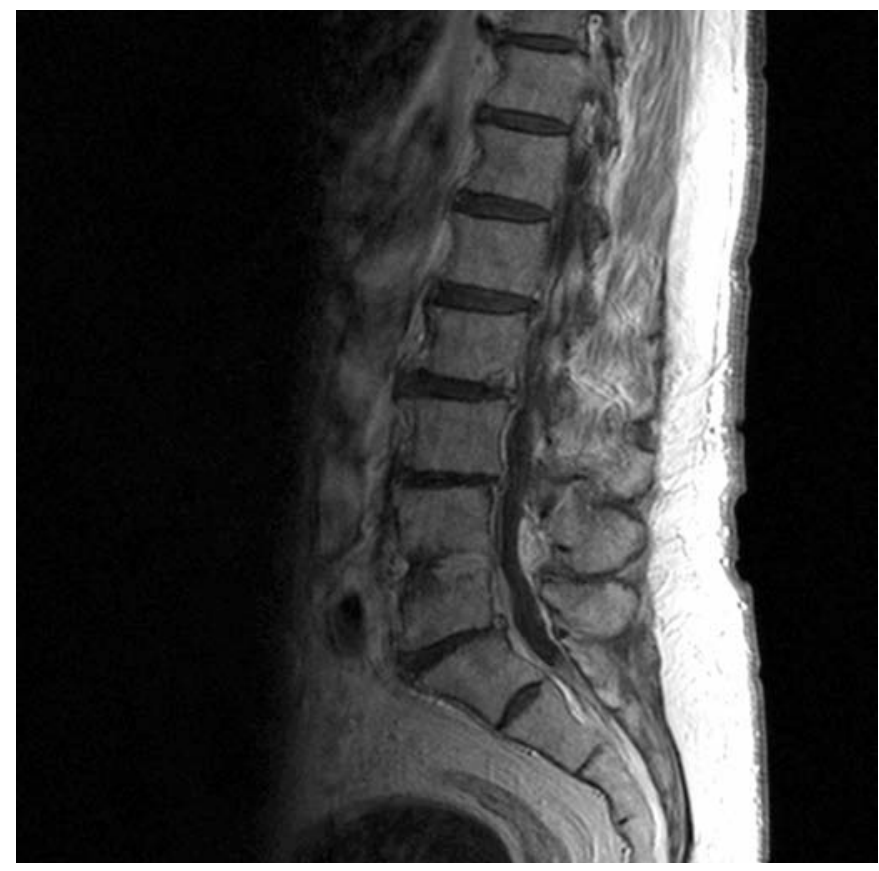

Fig. 1. Mala definición del contorno discal, con hiperseñal en T2 y áreas de hipodensidad en los platillos adyacentes; altamente sugestivo de espondilodiscitis.

La radiografía convencional puede ser negativa durante los primeros 10 días de la osteomielitis aguda, ya que la necrosis, descalcificación y esclerosis periféricas aún no son evidentes. El rastreo óseo con técnico 99 y la resonancia magnética nuclear son estudios muy sensibles que permiten un diagnóstico más precoces en más del $80 \%$ de los casos (8).

F. Marcos Sánchez, M. I. Albo Castaño, S. Casallo Blanco, M. Vivas del Val, A. Vizuete Calero, L. de Matías Salces

Servicio de Medicina Interna. Hospital Nuestra Señora del Prado. Talavera de la Reina. Toledo

1. Osiyemi O, Dickinson G. Gram-positive pneumonia. Curr Infect Dis Rep 2000; 2: 207-14.

2. Hoban DJ, Biedenbach DJ, Mutnick AH, Jones RN. Pathogen of ocurrence and susceptibility patterns associated with pneumonia in hospitalized patient in North-America. Results of the SENTRY Antimicrobial Surveillance-Study 2000. Diagn Microbiol Infect Dis 2003; 45: 279-85.

3. El-Solh AA, Sikka P, Ramadan F, Davies J. Etiology of severe pneumonia in the very elderly. Am J Respir Crit Care Med 2001; 163: 645-51.

4. Sethi S. Bacterial pneumonia. Managing a deadly complication of influenza in older adults with comorbid disease. Geriatrics 2002; 57: 56-61.

5. Moreillas P, AI Que Y, Glauser MP. Staphylococcus aureus (incluido el síndrome del shock tóxico). En Enfermedades Infecciosas. Principios y práctica. de Mandell GL, Bennett JE y Dolin R. Editorial Elsevier. Madrid 2006; 2321-51

6. Lew DP, Waldrogel FA. Osteomyelitis. N Engl J Med 1997; 336: 9991007.

7. Stengel D, Bauwens K, Sehouli J, Ekkernkamp A, Porzsalt F. Systematic review and meta-analysis of antibiotic therapy for bone and joint infections. Lancet Infect Dis 2001; 1: 175-88.

8. Bonhoeffer J, Haeberle B, Schaad UB, Heininger U. Diagnosis of acute haematogenous osteomyelitis and septic arthritis: 20 years-experience at the University Children's Hospital Basel. Swiss Med Wkly 2001; 131: $575-81$. 